\title{
Under Construction: Classification of Hepatitis B Virus Genotypes and Subgenotypes
}

\author{
Stephan Schaefer ${ }^{a}$ Lars Magnius $^{b}$ Helene Norder ${ }^{b}$ \\ a Institut für Medizinische Mikrobiologie, Virologie und Hygiene, Medizinische Fakultät, Universität Rostock,

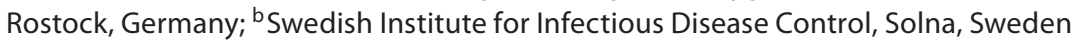

Hepatitis B virus (HBV) genotypes [1-6] and subgenotypes [7-12] have an impact on the course of disease and treatment decisions. In Germany, HBV genotyping is recommended before starting interferon therapy treatment of HBV infection [13]. Thus, an accurate and universal system of classification is of prime importance.

Several largely overlapping definitions for HBV genotypes have been presented by leading experts in this field in the past [4, 14-17]. However, due to the lack of universally accepted rules, irregularities have accumulated within the last 20 years of HBV genotype research. Some of these are found below.

(1) In a letter to the editor in this issue of Intervirology Ahn et al. (pp. 321-322) raise an important point. The assignation of subgenotypes $\mathrm{C} 1$ and $\mathrm{C} 2$ to clades is contradictory in the literature. As outlined by Ahn et al. there are two influential papers in which $\mathrm{C} 1$ following the nomenclature of Norder et al. [4] is C2 according to the classification of Huy et al. [18] and vice versa. However, regarding the figure in the letter, an uninitiated reader might get the impression that Huy et al. [18] also defined subgenotypes C3-C5. Also, only C1-C4 were described by Norder et al. [4]. C5 was described by Sakamoto et al. [19] in 2006. The reason for the discrepancies in nomenclature would have been more obvious if the references in the figure had been Huy et al. [18] and Norder et al. [4], respectively.

\begin{tabular}{ll}
\hline KARGER & $\odot$ 2009 S. Karger AG, Basel \\
0300-5526/09/0526-0323\$26.00/0 \\
$\begin{array}{l}\text { Fax +41 61 306 1234 } \\
\begin{array}{l}\text { E-Mail karger@karger.ch } \\
\text { www.karger.com }\end{array}\end{array}$ & $\begin{array}{l}\text { Accessible online at: } \\
\text { www.karger.com/int }\end{array}$
\end{tabular}

(2) Sequencing of only parts of the HBV genomes led to the tentative suggestion of subgenotypes A4 and A5 [20]. In an article in Emerging Infectious Diseases sequencing whole genomes of tentative A4 isolates, Andernach et al. [21] now group this subgenotype into the clade of A5.

(3) Based on whole genome sequencing two new subgenotypes have been called C6 in two contemporaneous publications. C6 has been identified in the Philippines [22] and Papua, Indonesia [23]. Isolates from these two publications map into two clades with a divergence of $5.1 \%$ and thus make up a new subgenotype $\mathrm{C} 7$ from the Philippines [Schaefer S, unpublished].

(4) A similar problem seems to arise with subgenotype D6. There are two concurrent publications that describe a new subgenotype D6 in Tunisia [24] and Papua, Indonesia [23].

(5) Regarding the delimitation of subgenotypes, these have been described as the major divisions within the phylogenetic trees in genotypes by Norder et al. [4]. Later on Kramvis et al. [14] defined subgenotypes as differing by at least $4 \%$ and supported this by robust bootstrapping data, although yielding largely overlapping results with the definition by Norder et al. [4]. This competing definition is partly contradictory to the original paper [4], where 4 major clades of genotype D, designated D1-D4, were described with an overall divergence for some of these clearly below $4 \%$ [25]. However, these subgenotypes

Stephan Schaefer, Prof. Dr. med., Institut für Medizinische Mikrobiologie Virologie und Hygiene, Medizinische Fakultät, Universität Rostock Schillingallee 70, DE-18057 Rostock (Germany)

Tel. +49381 494 5920, Fax +493814945925

E-Mail stephan.schaefer@med.uni-rostock.de 
are supported by robust bootstrapping values and are now widely accepted.

(6) Recombination in HBV isolates is common [26], e.g. subgenotype $\mathrm{B} 1$ is a recombinant between small parts of genotype C and subgenotype B2 [27]. In 2008 a new genotype I was described by Tran et al. [28]. Isolates of this clade seem to be widespread in South East Asia and many additional isolates were described in Vietnam [28] and Laos [29]. However, this genotype had already been described by Hannoun et al. [30] as a recombinant. Because the tentative genotype $\mathrm{I}$ is a complex recombination of several human and even gibbon HBV sequences, the designation genotype has been questioned by leading experts from the field [15]. However, the exact parental strains remain to be defined for genotype I as well as genotype G [31]. This is in great contrast to the first intergenotypic $\mathrm{HCV} 2 \mathrm{k} / \mathrm{lb}$ recombinant were the parental strains are easily classifiable within already established HCV subtypes [32].

Taken together, there are several points in HBV classification that need mending. To solve the issue we suggest an international consensus with a universal recommendation on how to delimit HBV genotypes and subgenotypes that all experts in the field agree on. In addition, this group of experts will make suggestions to the International Committee on Taxonomy of Viruses (ICTV) containing a list of HBV genotypes and subgenotypes. For each subgenotype a prototype genome should be selected derived from an $\mathrm{HBeAg}$-positive source to avoid phylogenetically irrelevant substitutions (in general the first isolate identified, if not too dissimilar to the consensus of that genotype or subgenotype). After careful analysis, the ICTV should officially acknowledge the rules for HBV classification and HBV subgenotypes.

For the time being we suggest following the widely used definitions, i.e.:
(1) Use the designation for subgenotypes $\mathrm{C} 1$ and $\mathrm{C} 2$ according to Huy et al. [18], since although they were designated as subgroups in the original paper their designations have been widely used for the corresponding subgenotypes.

(2) Group HBV subgenotype following the clade definitions of Norder et al. [4].

(3) The delimitation of new subgenotypes should be based on comparisons with previously described subgenotypes of that particular genotype by pair-wise comparisons and be supported by strong bootstrapping values.

(4) The tentative subgenotype C6 from the Philippines [22] will be renamed C7.

Apart from these - personal - recommendations, we suggest the following points for consideration by the expert committee for a universal HBV classification scheme.

(1) A new genotype should diverge by less than $8 \%$ at pair-wise comparisons of complete genomes [33]. The strain defining a new genotype should not be the result of a recent recombination, where the parental strains may be easily classifiable.

(2) New genotypes/subgenotypes should only be suggested on the background of complete genome sequences of more than one isolate.

(3) If feasible, the ICTV should be contacted during the review process when a new clade with a suggested new designation has been submitted. Only after the ICTV has declared that this new designation is not claimed by a contemporaneous submission in another journal will this designation be used in the accepted and published version.

(4) Reviewers should take care that correct and actual designations are used.

Taken together, Ahn et al. have raised an important point that should be taken care of in a timely manner. Coordinated actions from leading experts from the HBV genotype field and the ICTV are needed.

\section{References}

1 Chu CJ, Lok AS: Clinical significance of hepatitis B virus genotypes. Hepatology 2002; 35:1274-1276

-2 Kramvis A, Kew M, Francois G: Hepatitis B virus genotypes. Vaccine 2005;23:24092423.

$\checkmark 3$ Miyakawa Y, Mizokami M: Classifying hepatitis $B$ virus genotypes. Intervirology 2003; 46:329-338.
Norder H, Couroucé AM, Coursaget P, Echevarria JM, Leef SD, Mushahwar IK, Robertson BH, Locarnini S, Magnius LO: Genetic diversity of hepatitis B virus strains derived worldwide: genotypes, subgenotypes, and HBsAg subtypes. Intervirology 2004; 47: 289-309.

5 Schaefer S: Hepatitis B virus - significance of genotypes. J Viral Hepat 2005;12:111-124.
6 Kramvis A, Kew MC: Relationship of genotypes of hepatitis B virus to mutations, disease progression and response to antiviral therapy. J Viral Hepat 2005;12:456-464.

7 Tanaka Y, Mukaide M, Orito E, Yuen MF, Ito K, Kurbanov F, Sugauchi F, Asahina Y, Izumi N, Kato M, Lai CL, Ueda R, Mizokami M: Specific mutations in enhancer ii/core promoter of hepatitis B virus subgenotypes $\mathrm{C1}$ / $\mathrm{C} 2$ increase the risk of hepatocellular carcinoma. J Hepatol 2006;45:646-653. 
8 Truong BX, Yano Y, Seo Y, Phuong TM, Tanaka Y, Kato H, Miki A, Utsumi T, Azuma T, Trach NK, Mizokami M, Hayashi Y, Kasuga $\mathrm{M}$ : Variations in the core promoter/precore region in $\mathrm{HBV}$ genotype $\mathrm{C}$ in Japanese and Northern Vietnamese patients. J Med Virol 2007;79:1293-1304.

-9 Wang Z, Tanaka Y, Huang Y, Kurbanov F, Chen J, Zeng G, Zhou B, Mizokami M, Hou $\mathrm{J}$ : Clinical and virological characteristics of hepatitis B virus subgenotypes Ba, C1, and C2 in China. J Clin Microbiol 2007;45:14911496.

-10 Wang Z, Hou J, Zeng G, Wen S, Tanaka Y, Cheng J, Kurbanov F, Wang L, Jiang J, Naoumov NV, Mizokami M, Qi Y: Distribution and characteristics of hepatitis $\mathrm{B}$ virus genotype C subgenotypes in China. J Viral Hepat 2007; 14:426-434.

- 11 Yuan J, Zhou B, Tanaka Y, Kurbanov F, Orito E, Gong Z, Xu L, Lu J, Jiang X, Lai W, Mizokami M: Hepatitis B virus (HBV) genotypes/ subgenotypes in China: mutations in core promoter and precore/core and their clinical implications. J Clin Virol 2007;39:87-93.

$\checkmark 12$ Sung JJ, Tsui SK, Tse CH, Ng EY, Leung KS, Lee KH, Mok TS, Bartholomeusz A, Au TC, Tsoi KK, Locarnini S, Chan HL: Genotypespecific genomic markers associated with primary hepatoma based on complete genomic sequencing of hepatitis B virus. J Virol 2008;82:3604-3611.

$\checkmark 13$ Cornberg M, Protzer U, Dollinger MM, Petersen J, Wedemeyer H, Berg T, Jilg W, Erhardt A, Wirth S, Schirmacher P, Fleig WE, Manns MP: The German guideline for the management of hepatitis B virus infection: short version. J Viral Hepat 2008;15(suppl 1):1-21.

- 14 Kramvis A, Arakawa K, Yu MC, Nogueira R, Stram DO, Kew MC: Relationship of serological subtype, basic core promoter and precore mutations to genotypes/subgenotypes of hepatitis B virus. J Med Virol 2008;80:2746.

15 Kurbanov F, Tanaka Y, Kramvis A, Simmonds P, Mizokami M: When should 'I' consider a new hepatitis B virus genotype? J Virol 2008;82:8241-8242.
6 Norder H, Couroucé AM, Magnius LO Complete genomes, phylogenetic relatedness, and structural proteins of six strains of the hepatitis B virus, four of which represent two new genotypes. Virology 1994;198:489503.

17 Okamoto H, Tsuda F, Sakugawa H, Sastrosewinjo RI, Imal M, Miyakawa Y, Mayumi M: Typing hepatitis B virus by homology in nucleotide sequence: comparison of surface antigen subtypes. J Gen Virol 1988;69: 2575-2583.

18 Huy TT, Ushijima H, Quang VX, Win KM, Luengrojanakul P, Kikuchi K, Sata T, Abe K: Genotype $\mathrm{C}$ of hepatitis B virus can be classified into at least two subgroups. J Gen Virol 2004;85:283-292.

19 Sakamoto T, Tanaka Y, Orito E, Co J, Clavio J, Sugauchi F, Ito K, Ozasa A, Quino A, Ueda R, Sollano J, Mizokami M: Novel subtypes (subgenotypes) of hepatitis $\mathrm{B}$ virus genotypes $\mathrm{B}$ and $\mathrm{C}$ among chronic liver disease patients in the Philippines. J Gen Virol 2006; 87:1873-1882.

20 Olinger CM, Venard V, Njayou M, Oyefolu AO, Maiga I, Kemp AJ, Omilabu SA, le Faou A, Muller CP: Phylogenetic analysis of the precore/core gene of hepatitis B virus genotypes $\mathrm{E}$ and $\mathrm{A}$ in West Africa: new subtypes, mixed infections and recombinations. J Gen Virol 2006;87:1163-1173.

21 Andernach IE, Nolte C, Pape JW, Muller CP Hepatitis B virus in Haiti: an unusual subgenotype $\mathrm{A}$ and the conspicuous absence of typical West-African genotypes in African descendants. Emerg Infect Dis, in press.

22 Cavinta L, Sun J, May A, Yin J, von Meltzer M, Radtke M, Barzaga NG, Cao G, Schaefer $S$ : A new isolate of hepatitis B virus from the Philippines possibly representing a new subgenotype C6. J Med Virol 2009;81:983-987.

23 Utsumi T, Lusida MI, Yano Y, Nugrahaputra VE, Amin M, Juniastuti, Soetjipto, Hayashi Y, Hotta $\mathrm{H}$ : Complete genome sequence and phylogenetic relatedness of hepatitis B virus isolates in Papua, Indonesia. J Clin Microbiol 2009;47:1842-1847.
4 Meldal BH, Moula NM, Barnes IH, Boukef K, Allain JP: A new hepatitis B virus subgenotype, D7, in Tunisian blood donors. J Gen Virol 2009;90:1622-1628.

25 Tallo T, Tefanova V, Priimagi L, Schmidt J, Katargina O, Michailov M, Mukomolov S, Magnius L, Norder H: D2: major subgenotype of hepatitis B virus in Russia and the Baltic region. J Gen Virol 2008;89:18291839.

26 Simmonds P, Midgley S: Recombination in the genesis and evolution of hepatitis B virus genotypes. J Virol 2005;79:15467-15476.

27 Sugauchi F, Kumada H, Sakugawa H, Komatsu $\mathrm{M}$, Niitsuma $\mathrm{H}$, Watanabe $\mathrm{H}$, Akahane Y, Tokita H, Kato T, Tanaka Y, Orito E, Ueda R, Miyakawa Y, Mizokami M: Two subtypes of genotype $\mathrm{B}$ ( $\mathrm{Ba}$ and $\mathrm{Bj}$ ) of hepatitis $\mathrm{B}$ virus in Japan. Clin Infect Dis 2004;38:12221228.

28 Tran TT, Trinh TN, Abe K: New complex recombinant genotype of hepatitis $\mathrm{B}$ virus identified in Vietnam. J Virol 2008;82:56575663.

29 Olinger CM, Jutavijittum P, Hubschen JM, Yousukh A, Samountry B, Thammavong T, Toriyama K, Muller CP: Possible new hepatitis $\mathrm{B}$ virus genotype, southeast Asia. Emerg Infect Dis 2008;14:1777-1780.

30 Hannoun C, Norder H, Lindh M: An aberrant genotype revealed in recombinant hepatitis B virus strains from Vietnam. J Gen Virol 2000;81:2267-2272.

31 Stuyver L, De Gendt S, Van Geyt C, Zoulim F, Fried M, Schinazi RF, Rossau R: A new genotype of hepatitis B virus: complete genome and phylogenetic relatedness. J Gen Virol 2000;81:67-74.

32 Kalinina O, Norder H, Mukomolov S, Magnius LO: A natural intergenotypic recombinant of hepatitis $\mathrm{C}$ virus identified in St. Petersburg. J Virol 2002;76:4034-4043.

33 Arauz-Ruiz P, Norder H, Robertson BH, Magnius LO: Genotype H: a new Amerindian genotype of hepatitis B virus revealed in Central America. J Gen Virol 2002;83:20592073. 